\title{
The Problem of Ridicule in Henry Fielding's JOSEPH ANDREWS
}

\begin{abstract}
Starting his career as a provocative dramatist, generally criticised for open political satire and indecency of his plays, Henry Fielding developed into one of the most prominent eighteenth-century novelist and had to work hard to build a reputation which would correspond with the newly developing sensibilities of the reading audiences. The article considers the transition in Fielding's career in the context of changing demands on politeness in society and provides analysis of his first novel, Joseph Andrews, which links his technique of the true ridiculous to William Hogarth's fight against sham values and Lord Shaftesbury's idea of freedom of laughter. It also explains how this method helped Fielding create consciously ambiguous characters and make profound moral statements while keeping the possibility to entertain his readers through comedy.
\end{abstract}

Keywords

Novel; satire; politeness; ridicule; decorum

In the long $18^{\text {th }}$ century, the work of Henry Fielding represents a milestone between the era of the Ancients and the separation from the old values in the form of the Moderns. His unique position between the two modes of thinking reflects pieces of both worlds - the fading world of the Ancients, which Fielding admired but could no longer belong to, and the developing space of the Moderns, who desired to depart from the old traditions and create their own values, representative of the self-forming middle spectrum of society. Despite the fact that Fielding was largely indebted to the satirical tradition of his predecessors, he managed to adapt to the new literary trends of his time and incorporate them into his writings. His ability to blend various traditions, ranging from the influence of the Augustans 
- namely, John Gay and Jonathan Swift - to the imitation of the ancient models like Virgil or Milton, to the impact of the foreign tradition, for example, the works of Cervantes and Scarron, to his contemporaries, especially Samuel Richardson, Addison and Steele, shows not only his genius but also the rich mixture of ideologies which was present at that time.

At the centre of these beliefs was a struggle for social refinement in the form of politeness, which had been promoted by the thinkers and artists of the time. Although eighteenth-century definitions of what exactly is 'polite' may differ in details, Philip Carter identifies three essential principles on which eighteenthcentury commentators focused when defining politeness: propriety or decorum, elegance of manners or the quality of behaving with elegant complaisance, and the display of generosity and accommodation to one's companions (21). The call for improved standards of behaviour was reflected especially in the work of "the most influential early eighteenth-century polite theorists, among them Anthony Ashley Cooper, third Earl of Shaftesbury, and later the periodical essayists Joseph Addison and Richard Steele" (24). This great social project was also pursued by writers and painters like Henry Fielding, William Hogarth, Samuel Richardson and others, who contributed to the overall discussion and formation of understanding of the new personal and social virtues. The whole of society's endeavour to reform manners and break free from the old patterns and values of the preceding generations became an opportunity for the thinkers and artists to have a say in forming the future system of moralities and to create models of behaviour against which people could be judged.

This article explores Henry Fielding's career transition from a successful controversial playwright to a novelist with an ambition to actively engage in influencing general public in its perception of newly developing moral structures. The analysis of his two early texts, Shamela and Joseph Andrews, demonstrates Fielding's struggle to reconcile the satirical tradition of his predecessors with the literary demands of the Moderns while maintaining his own bold and distinctive approach, heavily influenced by the experience in theatre early on. Moving from parodic and burlesque representations typical of his first short prose, Shamela, Fielding is found to carefully define his position among the existing genres and explain his use of burlesque and ridicule in Joseph Andrews. In order to prevent accusations of lowness in his writing, he comes up with a concept of the true ridiculous, which originated in the aesthetics of Lord Shaftesbury but also reflects the methods of Fielding's friend, painter and engraver, William Hogarth. As he uses the satirical technique of the true ridiculous, Fielding is able to retain some space for the free exercise of his wit and, at the same time, to provide more profound commentaries on human nature when he contrasts, parallels and mirrors various characters, inviting readers to reassess their initial moral judgments while the plot of the novel develops.

Under the influence of Ian Watt's grounding study, The Rise of the Novel, Henry Fielding has been in many cases presented as Samuel Richardson's counterpart in the dichotomy of two rival early novelists who responded to changing sensibili- 
ties and interests of the readers in very distinct ways. Drawing on the commentaries of contemporary critics, especially Samuel Johnson and James Boswell, Watt stresses the difference between their techniques of portraying characters and also the types of realism they create. Whereas Richardson is marked as a founder of psychological realism who "takes us deeper into the inner workings of the human machine", Fielding is concerned with the external view and "engaged in the exploration of a vaster and equally intricate mechanism, that of human society as a whole" (Watt 1957: 289). Despite the fact that Nancy Armstrong's Desire and Domestic Fiction has shown Richardson's work as praised more by Johnson and also more significant for the development of the novel of domesticity, Fielding outsold Richardson in number of volumes and was by no means less important as an influence over the readers of the time (Raven 1987). Since the frequent comparison of Fielding's work with Richardson's sometimes results in reducing his writings into a mere reference for Richardson's moral-forming project, it has been suggested by Fielding scholars like Robert Hume and Angela Smallwood that there is an urgent need to present Henry Fielding under a new perspective, liberating him from the assigned role of Richardson's counterpart, which would allow us to see his work in a different light. As Hume claims, "Fielding and Richardson are both fundamentally moralistic writers, but seeing Fielding mostly in juxtaposition to his great rival severely distracts us from his greater social and generic range, his originality, his sociopolitical agendas and his consistently adventurous experimentalism" (2010: 236). Therefore, the article aims to present Fielding as a unique artist and focuses on the manner in which his work adapts to the requirements on politeness and new sensibilities of his time.

Apart from being a playwright, a columnist and a novelist, Fielding was, above all, a satirical writer. Fielding's contemporaries saw satire as "a dangerous weapon, dangerous not only to society generally, but also to the satirist" (Elkin 1973: 44). Since satirical writers were often severely penalised for challenging the powerful, reflecting society through satire did not always put Fielding in the easiest position. As Martin Battestin documents in Fielding's biography, openly politically satirical performances like Gay's The Beggars' Opera and Fielding's Pasquin as well as The Historical Register did not go unnoticed by the ministry, who regarded Fielding "as the all too effective instrument of the Opposition" (1989: 223). His open criticism of the Prime Minister, Sir Robert Walpole, and complaints about indecency of Fielding's plays resulted in closing most of the theatres in London under the Licensing Act in 1737, and "no one either in or out of the government doubted that, whatever other convenient uses the minister might put it to, the Theatrical Licensing Act was instituted to put a stop to Fielding's play-writing" (234). His rocketing career of a popular playwright, consequently, fell into pieces when he lost his theatre in Drury Lane and suddenly was deprived of his usual means of sustenance. With a family to feed, Fielding had hard times supporting himself financially and had to take up a number of hack-writing jobs in order to survive. In fact, when he was starting the career of a prose writer with his short piece Shamela, he did it in a sponge house where he was imprisoned for 
failing to pay his debts. Considering the very often base content of his plays and careless lifestyle, which came along with his sociability and love of merry company, Fielding had a lot of trouble persuading the novel-reading audiences that he might be a respectable writer who has something to say about the manners of the time or could even moralise the newly forming society.

His personal reputation and history of a profligate cheeky playwright was, nevertheless, not the only difficulty he had to overcome when assuring the public about his respectability. As it was generally dealing with human flaws and failings, the genre of satire itself was considered naturally suspicious and associated with slandering and scandals. Especially the works of Swift and Pope's Dunciad were severely criticised at the time for their explicitness and bitterness (Elkin 1973: 44). For example, Richardson found Swift insufferable and recommended some of his writings to be burned by the Common Hangman (54). On the other hand, satire as a literary form was not completely condemned and most writers to a smaller or greater extent used it in their work. As it follows, the requirement of the age was not abandonment of satire as such, but its refinement and adjustment to the new sensibilities. As Elkin states, "the obscene antics of Pope's dunces and Swift's yahoos were too much for those Augustans who cherished standards of refinement and propriety, and who were advocating satire which would be both gentler and more genteel" (59). Therefore, Addison, Steele, Richardson and later modern writers who criticised satirists of the first decades of the century were very concrete in their complaints and never abandoned ridicule as a possibility to influence the reader.

Despite the general negative connotations of satire as a genre, Fielding fell back on his previous successful career of a satirist and did not hesitate to use comical mockery to draw attention to human vices in his novels. His work remains indebted to the preceding tradition of Augustan satire - namely, to Jonathan Swift - "who influenced Fielding in forming his own ironic style and his sense of the uses of ridicule" (Battestin 1989: 405). Also Fielding's great esteem for ancient satirists, like Virgil and Ovid, to whom he frequently and proudly refers in his later novels, made researchers explore his writings in the connection with the Ancients. Since the 60s up to the 90s of the twentieth century, Fielding's work was linked to the tradition of the Ancients and read in this context by the most influential critics, like Martin Battestin, Ronald Paulson, Claude Rawson and J. Paul Hunter. Nevertheless, Fielding's effort to boost his reputation by putting his prestigious Etonian learning on display and associating himself with the well-established literary circle of the previous era did not make much impression on the new generation of readers, who often did not even share his educational background. Instead, Fielding had to prove himself capable of bringing new ideas into the ongoing debate established by Addison and Steele about the requirements of the forming bourgeois taste.

As Ashley Marshall pointed out, even though Fielding openly admires the work of Swift and Pope, there are many differences between the satire written by the Scriblerians and by Fielding. In Marshall's own words: 
however familiar he may have been with the work of these writers, he does not appear to have been very directly influenced by them. Finding general parallels between his works and theirs is easy enough for a well-trained critic, but that an impartial arbiter presented with the relevant primary material would identify Fielding as a Scriblerian manqué seems highly unlikely. Fielding is doing something different. (Marshall 2011: 44)

Although the Augustans generally believed that "smiling satire instructs and reforms more effectively than savage satire because it pleases more readily" (Elkin 1973: 146), Swift's otherwise entertaining commentaries on human society often appeared very resentful and almost misogynist to later generations. Such negative overtones did not correlate with the mid-century enthusiastic view of human nature, inspired by, among others, the works of the third Earl of Shaftesbury. As opposed to Swiftian critical and rather bitter satirical attacks on human vices, Fielding's writing displays a lot of positive ideas about human nature.

Also, he does not really make a pledge to the literary mission the previous generation had of preserving classical ideals and especially looking for one ideal for society based on reason and order. As Elkin claims, Englishmen in the late seventeenth century felt

they could discern beyond the realities of the present and the immediate past the ideal of a society founded on permanent principles of order, and infused with the radiance and grandeur of the heroic world of antiquity, though without the embarrassing imperfections of that world, such as its moral lapses and fantastic superstitions. (Elkin 2011: 7)

Unlike, for example, Swift and his Houyhnhnms, Fielding does not offer any visions of an ideal society, nor does he base his ideas of virtue on reason and order. Moreover, his treatment of heroes involves mockery and he generally challenges the traditional notions of heroism. All in all, lacking in seriousness and devotion to previous ideals, his style is inclined to comedy, which "encourages us to laugh freely ... for it enlarges our sense of the possibilities of life" rather than satire, which "is always fundamentally judicial" (13). One striking distinction from the work of the Augustans is thus Fielding's focus on comicality and burlesque, which very much differs from the punitive and often angry tone characteristic of the previous tradition (Marshall 2011: 42). Under the influence of the stage, which was closely associated with comic realism, Fielding breaks free from the severe satirical tone of his predecessors while still following the aim of "satirical exhibition of the improprieties and follies of mankind" (15) - the aim both comedy and satire shared.

In his first attempt at prose, he openly parodies, among others, Richardson's best-seller about an honourable servant Pamela Andrews, who became an admired model example for young girls. As he portrays a rather crude and down-toearth version of the servant's love story with her master, he "travesties romance by revealing the real schemer beneath the pious phrases and coyness of Richardson's heroine" (Paulson 1967: 111). Whereas in Richardson's original story, 
Pamela is a victim of her master's uncontrolled desires, in Fielding's parody, he is depicted as a fool, manipulated by a clever poor girl into elevating her social status through marriage. By turning the implausibly honourable maid into a smart country wench, who uses unlearned language of the common people and looks out for ways to better her situation, Fielding exposes the artificiality of Richardson's scenarios and invites the reader to have a good laugh at both master Booby's weakness and Shamela's base reasoning.

To achieve the desired comical effect, Fielding makes Shamela misspell words in her letters "as any lady's maid in her nonage would be expected to," but also shows her to be "a vulgar horror - though a most amusing horror" (Johnson 61: 25). Not only does she compare favourably with her master in cunningness of her plotting, she rivals him in the coarseness of his provocations when, for example, to his angry exclamation: "I have a great Mind to kick your A-", she replies: "You, kiss - ", and then, when she flings from his arms to safety, she mockingly sighs describing the situation in a letter to her mother in the manner of Pamela's self-pitying commentaries: "Oh what a prodigious Vexation it is to a Woman to be made a Fool of." Finally, after her fellow-servant advices her to turn Mr. Booby's affection into some good money, she opposes her, exclaiming: "No, Mrs. Jervis, nothing under a regular taking into Keeping, a settled Settlement, for me, and all my Heirs, all my whole Life-time, shall do the Business" (2010: Letter VI). Fielding's mockery of Pamela's pathetic passivity in dealing with her master's advances, which he distorts into sham and calculation, is therefore always presented in a funny, humorous way, asking the readers to sober up from Richardson's elevated prototype.

As it could be expected, debasing the generally beloved Pamela did not meet with positive acceptance of the middle-class readers. Although joyfully lauded in The London Magazine by a short anonymous poem, the parody was scorned by the influential literary circle surrounding Richardson, namely by Aaron Hill, who praised Pamela and, in his commentary, referred to "the oblique reputation weaker writers endeavour to draw, from a distorted misuse of her name" (Paulson and Lockwood 1967: 117). Despite the probable popularity the parody enjoyed among Londoners, Shamela thus did not help its author in his ambition to become a respected novelist.

After the scornful reception of his anonymous piece, Fielding was fully aware that he needs to seek approval of the new audiences and carefully position himself between genres. While experimenting with new types of narrative and satirical methods, he had to adjust the style of his prose to the set requirements of the age. In the preface to Joseph Andrews, the first prose published under his name, he carefully distances his comic romance from serious romance, defining his narrative as:

a comic epic poem in prose; differing from comedy, as the serious epic from tragedy: its action being more extended and comprehensive; containing a much larger circle of incidents, and introducing a greater variety of characters. It differs from the serious romance in its 
fable and action, in this; that as in the one these are grave and solemn, so in the other they are light and ridiculous: it differs in its characters by introducing persons of inferior rank, and consequently, of inferior manners, whereas the grave romance sets the highest before us: lastly, in its sentiments and diction; by preserving the ludicrous instead of the sublime. In the diction, I think, burlesque itself may be sometimes admitted; of which many instances will occur in this work, as in the description of the battles, and some other places, not necessary to be pointed out to the classical reader, for whose entertainment those parodies or burlesque imitations are chiefly calculated. (Fielding 1967: 4)

Thus, he establishes comic satire as the main method of reflecting on society and communicating with his readers as opposed to merely providing them with a love story, which might by its example result in creating more illusions than understanding. ${ }^{1}$

The famous preface also carefully explains his satirical method. Although he makes effort to distance himself from common romance and assures the audiences that his novel should not be mistaken for second-rate entertainment, Fielding admits that his work contains burlesque, which was regarded as a trait of rather low types of literature. Therefore, remaining on thin ice with his critics, Fielding stresses that he

carefully excluded it from our sentiments and characters ... Indeed, no two Species of Writing can differ more widely than Comic and Burlesque: for as the latter is ever the exhibition of what is monstrous and unnatural, ... in the former we should ever confine ourselves strictly to nature, from the just imitation of which will flow all the pleasure we can this way convey to a sensible reader. (4)

The entertaining elements of burlesque, meaning exaggerated imitation or parody, used in Fielding's work are, then, handled with care and usually associated with some of the marginal characters so that the main figures of the story can be taken seriously and still serve their purpose in the writer's commentary on modern manners. The example of a character which bears marks of burlesque in the story is surely Beau Didapper, modelled on John, Lord Hervey (Fielding 1967: xxiii), who serves as a caricature of city beaus in general and gets mocked right in the description as

not entirely ignorant; for he could talk a little French and sing two or three Italian songs; he had lived too much to be bashful, and too much at court to be proud: he seemed not much inclined to avarice, for he was profuse in expenses; nor had he all the features of prodigality, for he never gave a shilling: no hater of women, for he always dangled after them; yet so little subject to lust, that he had, among those who knew him best, the character of great moderation in his pleasures; (312)

Also his physical features are distorted since he is ridiculously thin and hops rather than walks and his overall inabilities are topped with the lack of self-reflection 
and aptitude to laugh at any imperfection in another. Yet, his monstrosity is fully revealed when he tries to rape Fanny, taking advantage of pitch darkness in an inn where the whole company of travellers stayed on their journey. However, at the same time, his poor attempt is ridiculed when, by mistake, he enters the room of a middle-aged unattractive maid, Mrs. Slipslop, who gets a firm hold of him and accuses him of violating her chastity, which he never intended (331). Therefore, although Fielding includes an exaggerated depiction of a city beau in all the ugliness of his demeanour, he makes sure the character is treated with comicality and only plays an episodic role in the story.

Since burlesque was a literary trait typical of Fielding's previous career of a playwright and it stood behind the great success of his plays, it was a technique he did not want to part with. As W.R. Irwin confirms, "the venture into prose fiction ... was for Fielding a change of method, not of spirit. ... Fielding's comedy is essentially a recasting and an expansion of what have already been seen as the main characteristics of his literary satire" (180). Fielding's techniques, therefore, reflect the ambivalence between the previous literary tradition and the emerging flexible literary environment he became so comfortable with. On the one hand, he fully respects Shaftesbury's strict refusal of burlesque as something not "to be found in the writings of the ancients", but, at the same time, he tolerates its use in the writings of the moderns because, in his opinion, "it contributes more to exquisite mirth and laughter than any other; and these are probably more wholesome physic for the mind, and conduce better to purge away spleen, melancholy, and ill affections, than is generally imagined" (Fielding 1967: 5). Fielding's prevaricating between the theoretical requirements on restrictions of humour and his well-established know-how, which had won him popularity of theatre audiences, is thus not present only in the early stage of his transition from a scandalous playwright to a respectable novelist and a public figure. Although he generally complied with the commonly accepted new standards, he was always looking for new possibilities which allow for keeping the audiences well-entertained.

Apparently, he was not the only artist of the age facing such difficulties. ${ }^{2}$ His preface brings to help the example of his friend, William Hogarth, whose work he claims illustrates the difference between the crude principle of burlesque based on caricature of certain traits, in painting represented by caricatura, and his cycles on vices, which seem "to express Affections of Men on Canvas" and "appear to think" (7). Many times both of these artists had to defend themselves against criticism which presented them as "either 'low' or simply good at comedy, so that any aspirations they showed (in, say, painting sublime histories, writing serious art treatises or serious novels) were ridiculed or deplored" (Voogd 1981: 10). However, their work, as Fielding took great pains to stress, was aiming to do much more than merely entertain the reader. Their approach to satire shares another quality - they point to the consequences of their character's actions. Instead of using the technique of caricature, depicting a distorted trait, which makes something or someone appear monstrous, Hogarth portrays a story showing the consequences of characters' behaviour. As Fielding writes about him in The Champion of June 1740: 
I esteem the ingenious Mr. Hogarth as one of the most useful Satirists any Age hath produced. In his excellent Works we see the delusive Scene exposed with all the Force of Humour, and on casting our Eyes on another Picture, you behold the dreadful and fatal Consequence. I almost dare affirm that those two Works of his, which he calls the Rake's and the Harlot's Progress, are calculated even more to serve the cause of Virtue, and the Preservation of Mankind, than all the Folios of Morality which have ever been written. ${ }^{3}$ (1981: 42)

As Voogd remarks about the two satirists: "Hogarth, too, forces the reader to reassess his initial interpretations all the time, to peer under the mask presented, and discover the reality hidden under the glittering surface" (1981: 139). Hogarth's less explicit techniques of moral satire therefore proved to be inspirational for Fielding's concept of satirical writing, since both artists aim to use humour to expose the sham and affectation, which they see as the basis of human vice, but they also must refrain from using the criticised explicit and vulgar techniques of the previous era. So, in order to fulfil the expectations of social and literary critics, Fielding had to find a golden mean between the popular but offensive and the desired yet moralizing satirical narrative.

As the most discussed danger in satire was the possible misuse of ridicule and the overall malice of laughter, he made sure to distinguish between mean laughter and "the true ridiculous". In the preface to his first novel, Fielding insists that "the only Source of the true Ridiculous [...] is Affectation", which "proceeds from one of these two Causes, Vanity or Hypocrisy: for as Vanity puts us on affecting false Characters, in order to purchase Applause; so Hypocrisy sets us on an endeavour to avoid Censure, by concealing our Vices under an Appearance of their opposite Virtue" (1967: 8). Thus, he establishes the notion of ridicule as a weapon against social evils, which should help him reveal and correct the follies of mankind, as opposed to mere buffoonery designed purely to make somebody laugh. The concept of the true ridiculous also figures in the work of Lord Shaftesbury, to whom Fielding refers in the preface. Shaftesbury sees humour as "a means of liberation from patterns of action or thought that are life-destroying rather than life-giving" (Grean 1967: 120). He also implies that humour allows the mind "to view problems from various perspectives, and thus, it is the enemy of all pretence and falsity" (120). Consequently, Shaftesbury proposes to ridicule what is pretended, and offer different perspectives, which should lead to exposing falsity. To what extent it is possible to rely on ridicule as a test of truth remained unclear in Shaftesbury's texts and it was disputed by other thinkers throughout the century ${ }^{4}$. Nevertheless, his view of ridicule greatly overlaps with Fielding's concept of the true ridiculous and his method of exposing his readers to various points of view by contrasting scenes, characters and stories so that they can see the problems he criticises in a different light. This exercise of readers' minds was crucial to Fielding's aim to expose the vices of society and laugh his readers into refining their manners. Shaftesbury's inspiring but also controversial idea that wit should be exercised freely stayed at the core of Fielding's art as well as the eighteenthcentury struggle for refinement. As Shaftesbury states in his Characteristics, "all 
politeness is owing to liberty. We polish one another, and rub off our corners and rough sides by a sort of amicable collision" $(46)^{5}$. The satirical approach Fielding took in his novel-writing embraces such freedom and reflects individuals as well as various social groups. Interactions between his characters, therefore, allow for a more complex reflection of society and show that he is not afraid to make fun not only of human vices in general but also of concrete unwritten rules which bind us to create a certain public self-image.

The way Fielding treats his characters to mock social beliefs was very often entertaining, but his demand on constant judgment-making on the part of the reader was also quite confusing for the audiences. In Joseph Andrews, he creates a character of a gullible priest, Abraham Adams, whom he depicts in a number of humiliating situations. For example, on his way to the city, Parson Adams is attacked by dogs, loses his wig, is splashed with hot pig blood and even worse, ends in pig dung when visiting his fellow parson. Moreover, he is tormented by the Roasting Squire, who invites him into his house only to play a number of practical jokes on him. In his analysis of the novel, Simon Dickie explains such depiction by the influence of Fielding's preceding career of a playwright, who excels in entertaining the public with humorous characters and elements of slapstick type of comedy. As he argues, when "Adams is mocked, mimicked, tumbled to the ground, and scalded with hot soup, [...] Fielding provides his readers with a strikingly similar sequence of their favourite stage pranks" (2011: 165). Also Jill Campbell in her Natural Masques reads the roasting of Parson Adams as Fielding's exploration of "the possibility that satiric aggression is continuous with crude physical abuse" (1995: 103), which remains a part of readers' expectations. Although Fielding uses the well-working satirical customs to entertain his audiences, Parson Adams is not the real subject of satirical derision in the novel. When compared with other clerks - Parson Barnabas and Parson Trulliber, who indulge in drinking or even abuse people around them, Abraham Adams comes out as a slightly distracted but a good-hearted fellow at whom we might laugh at times but whom we pardon and love. Even in the preface to the novel, Fielding finds it important to explain his treatment of the character:

It is designed a character of perfect simplicity; and as the goodness of his heart will recommend him to the good-natured, so I hope that the character's good-heartedness will excuse me to the gentlemen of his cloth; for whom, while they are worthy of their sacred order, no man can possibly have a greater respect. They will therefore excuse me, notwithstanding the low adventures in which he is engaged, that I have made him a clergyman; since no other office could have given him so many opportunities of displaying his worthy inclinations. (1967: 11)

It follows that the character of Adams does not represent a satirical portrayal of the clergy itself, but incorporates some comic elements, which criticise concrete traits of absent-minded self-serving preachers.

Although Parson Adams's imperfections make him end up in a number of laughable situations, the rather simple and crude type of comedy generated by the 
treatment of this character was not supposed to be the source of the true ridiculous in the book. As ridiculousness, in Fielding's concept, comes from affectation, the revealing moment that discloses the ridiculous in the character is not the one when the parson slides in mud into a filthy pigsty, but when he is disgraced by his own hypocrisy. For instance, when Joseph's beloved Fanny is kidnapped by the Roasting Squire and Joseph weeps over the situation, Adam reproaches him for inappropriate behaviour and advises him to remain calm and reconcile to his misfortune (265). However, later in the story, when Adams is informed that his son has probably drowned, he bursts into tears himself and starts weeping. Like all the other Fielding's characters, Parson Adams cannot escape the principle of the true ridiculous and the criticism of affectation. As in many other cases, Fielding's parson is therefore portrayed as a character we laugh at and accept as good at the same time, but certainly not as a character we would see as a model of a priest. On the other hand, as Fielding destroys the expected decorum of this priest-like figure without turning him into a truly despicable character, he makes him more approachable and human.

The issue of keeping decorum of certain types of characters while exposing their hypocrisy remained a challenge for the pioneer novelist, especially as far as highly-positioned women are concerned. Apart from contrasting characters, like in the case of Adams and other priests in Joseph Andrews, Fielding takes to paralleling scenes to attack the well-established conventions abused by people in higher social positions. For instance, when Lady Booby seduces Joseph, she is described with appropriate delicacy as a woman of high social status, who, when tempting Joseph, "accidentally put her hand on his" and "discovered one of the whitest Necks that ever was seen" (1967: 29-30). Although her attempt to seduce Joseph might seem sophisticated and innocent, the whole perspective changes after reading the very next chapter, in which the same attempt is made by Mrs. Slipslop, Lady Booby's waiting woman, who is a much coarser and more straightforward equivalent of her superior. Since she is of a lower social rank, Fielding can freely describe the crudity of her person and the awkwardness of her attempts, which parallel and highlight similar nature of the two acts. As opposed to Lady Booby, Mrs. Slipslop is described as "a hungry Tygress" or "a voracious Pike" (33), who bribes Joseph with "Tea, Sweetmeats, Wine and many other Delicacies" (32), tries to impress him with sophisticated expressions, which she constantly confuses, and reproaches the poor Joseph for not being grateful enough for such advances. By paralleling Lady Booby's actions with a more naturalistic scene, where another woman does essentially the same thing, but with less pretention, Fielding therefore strips her act off the pretended innocence and mockingly debases her without openly destroying the decorum of her position.

Ronald Paulson and Thomas Lockwood's collection of Fielding's reception by his contemporaries offers both positive and negative response to the novel, generally praising his characters and dialogues but getting at the lowness of his style. For example, Dr. George Cheyne talks about Fielding's "wretched Performance" which "will entertain none but Porters and Watermen" (1967: 118); on the other 
hand, in her letter to Catherine Talbot, the $18^{\text {th }}$ century poet, Elizabeth Carter, shows a lot of respect and admiration for Joseph Andrews, stressing the author's intention to point to "some particular instances of inhumanity which can only be hit in this kind of writing" and "certainly cannot be represented in too detestable a light as they are so severely felt by the persons they affect, and looked upon in too careless a manner by the rest of the world". She is also persuaded that "it must surely be a marvellous wrongheadedness and perplexity of understanding that can make anyone consider this complete satire as a very immoral thing, and of the most dangerous tendency" even though she "met with some people who treat it in the most outrageous manner" (123). Therefore, the lowness of some of Fielding's characters and style is understood by Carter as a part of his depiction of coarse realities of the lives of the lower classes - not necessarily something which is meant to be frown upon or scandalize fine people.

Not only Elizabeth Carter, but also other $18^{\text {th }}$-century public figures and French translators of this novel gave it a lot of credit and saw it as a moral piece of writing rather than an offensive one. For instance, Pierre Francois Guyot Desfontaines, who translated Joseph Andrews into French, comments on the novel in a fictive letter from an English Lady to Madame ***:

This Novel ... is considerably superior to all of your French novels ... What a tissue of insipidities and trifles is La Vie de Marianne! Le Paysan Parvenu is worth a little more: But what coarse features! What lowness! What descriptions! ... This is certainly not a Book of simple pleasures for the crowd: this is a Book of science and of unadorned morality, available to every one and in addition, it is a book in which one comes to understanding how we live in England. (128-129)

The striking variety in the reception of the novel reflects how unstable the expectations of polite representation of social groups were at the time. Fielding's introduction of characters from the lower ranks of society into the novel was met with both scorn and appreciation as realistic representation of society, and even though Joseph Andrews was criticised by some for its use of low humour, to many others it transgressed the limits of burlesque and developed into a complex satirical novel.

In conclusion, Fielding's satirical writing was influenced by his unique position between the Augustan tradition and the newly developing sensibilities of his own time. As opposed to Swift, whose satirical criticism rests on "a traditional assumption . . . about the human condition: that it is prey to subversion and unhappiness from within, that men are by mental constitution restless, irrational and unsatisfied, congenially prone to false needs and driven to supererogatory and destructive satisfactions" (Rawson 1985: 3), Fielding presents a more positive view of human nature, which stresses its fallibility but also innate goodness of men. Although he uses ridicule and irony like his predecessors, due to severe criticism of Swift and Pope's satirical methods Fielding had to come up with new techniques, which would be more appropriate for the modern taste. As a result, 
he presented an unconventional satirical method of the true ridiculous based on showing a mirror rather than distorting a trait that should be mocked. Intending to laugh the mankind out of its follies, instead of punishing human vices with the proverbial lash of satire, he creates characters not strictly virtuous or vicious, but rather ambiguous and hardly ever escaping the effects of comedy and satirical comments of the narrator, which makes them less acceptable as models of proper conduct, but also more relatable and realistic. At the same time, he carefully guides readers' judgments and asks them to reconsider their first impressions of his characters, leading them more and more into depths of revealing pretence and false moralities.

\section{Notes}

1 Michael McKeon argues in The Origins of English Novel that in Fielding's novels "the critique of the old, romancing histories is supplemented by a critique of the 'new romance' of naïve empiricism and its modernized methods of imposing on the credulity of the reader (1987: 383).

2 Ian A. Bell claims in his book Authorship and Authority that "accusations of 'low' style of writing quickly became a commonplace" (1994: 9).

3 Walter J. Ong makes an interesting commentary on generating understanding relevant to Fielding's method in his book Interfaces of the Word when he says: "The drive to symbolize intellection and understanding by vision, that is, to consider intellection and understanding by analogy with vision thus corresponds to the drive to objectify knowledge, to make it into something which is clearly thing-like, nonsubjective, yielding meaning not in depth but off of surface, meaning which can be spread out, explained." (1977: 140)

$4 \quad$ More details about the dispute are to be found in Stanley Grean's study Shaftesbury's Philosophy of Religion and Ethics: a Study in Enthusiasm in the chapter "Humor and Liberty".

5 Lawrence E. Klein further describes the connection between Shaftesbury's concept of liberty, his Whiggism and politeness in his essay "Liberty, Manners and Politeness in Early Eighteenth-Century England".

\section{References}

Armstrong, Nancy (1987) Desire and Domestic Fiction. London: Oxford University Press.

Battestin, Martin C. (1989) A Life. London: Routledge.

Bell, Ian A. (1994) Authorship and Authority. London: Longman Publishing.

Campbell, Jill (1995) Natural Masques. Standford: Stanford University Press.

Carter, Philip (2001) Men and the Emergence of Polite Society. Harlow: Pearson.

Dickie, Simon (2011) The Cruelty of Laughter. Chicago: University of Chicago Press.

Elkin. P.K. (1973) The Augustan Defence of Satire. London: Oxford University Press.

Fielding, Henry (1967) Joseph Andrews. Oxford: Clarendon Press.

Fielding, Henry (2010) Shamela. Project Gutenberg. E-book. https://www.gutenberg.org/ files/30962/30962-h/30962-h.htm

Grean, Stanley (1967) Shaftesbury's Philosophy of Religion and Ethics. Ohio: Ohio University Press.

Hume Robert (2010) Fielding at 300: Elusive, confusing, misappropriated, or (perhaps) obvious?. 
Modern Philology 108(2): 224-262. http://www.jstor.org/stable/10.1086/657591, accessed on 1 February, 2014.

Hunter, J. Paul (1975) Occasional Form. Baltimore: John Hopkins University Press.

Irwin, W.R. (1946) Satire and comedy in the works of Henry Fielding. ELH 13(3): 168-188. https:// www.jstor.org/stable/2871437, accessed on 9 February 2019

Johnson, Maurice (1961) Fielding's Art of Fiction. Philadelphia: University of Pennsylvania Press.

Klein, Lawrence E. (1989) Liberty, manners and politeness in early eighteenth-century England'.

The Historical Journal 32(3): 583-605. http://www.jstor.org/stable/2639534, accessed on 5

March, 2017.

Marshall, Ashley (2011) Henry Fielding and the Scriblerians. Modern Language Quarterly

72(1): 19-48.

McKeon, Michael (1987) The Origins of the English Novel 1600-1740. Baltimore: The John Hopkins University Press.

Ong, Walter J. (1977) Interfaces of the Word. Ithaca: Cornell University Press.

Paulson, Ronald (1967) Satire and the Novel in Eighteenth-century England. New Haven: London University Press.

Paulson, Ronald and Thomas Lockwood (1969) Henry Fielding: The Critical Heritage. London: Routledge.

Raven, James (1987) British Fiction, 1750-1770: A Chronological Check-List. University of Delaware Press.

Rawson, Claude (1985) Order From Confusion Sprung. New Jersey: Humanities Press.

Shaftesbury, Anthony Ashley Cooper (1900) Characteristics of Men, Manners, Opinions, Times, etc. Cambridge: Cambridge University Press.

Smallwood, Angela (1989) Fielding and the Woman Question: the Novels of Henry Fielding and Feminist Debate 1700-1750. New York: St Martin's Press.

Voogd, Peter Jan de (1981) Correspondences of the Arts. Amsterdam: Rodopi.

Watt, Ian (1957) The Rise of the Novel. Berkeley: University of California Press.

Dita Hochmanová has recently finished her Ph.D. at the Department of English and American Studies at Masaryk University in Brno, Czech Republic. Her research interests include the development of novel as a genre, satirical prose in eighteenth-century England, and masculinity studies. Her Ph.D. project focuses on the role of Henry Fielding's work in the forming of new gender models and politeness standards of his time.

Address: Mgr. Dita Hochmanová, Ph.D. Department of English and American Studies, Faculty of Arts, Masaryk University, Arna Nováka 1, 602 00, Brno, Czech Republic. [e-mail: 178804@mail. muni.cz] 